\title{
Income and Expenses of Eighth District Member Banks: 1975
}

\author{
JEAN M. LOVATI
}

IGHTH District member banks experienced a moderate increase in net income in 1975, a year of recovery and restoration. The financial strength of banks in the Eighth District generally improved during the year. Capital cushions were built up and debt was reduced.

In the early 1970 s when demand for credit was strong, many banks expanded their loans but frequently showed little growth in their capital accounts. Increased loan volume was accompanied, in many cases, by a reduction in cash assets and high grade short-term securities. However, in 1975 banks began to reverse previous trends, emphasizing more liquid instruments in their asset portfolios.

Net income of member banks in the Eighth Federal Reserve District rose 9 percent in 1975, slightly less than the 10 percent increase experienced in $1974 .^{1}$ A major factor accounting for this slower growth was the smaller volume of loans held by member banks. The effect on net income, however, was mitigated by lower interest expenses, which reflected both a reduced volume of obligations of member banks and lower average rates paid on them.

In general, Eighth District member banks fared better than the average of all member banks. Net income of all member banks in the nation rose 3.4 percent in 1975, less than half that for District member banks. Primarily because of greater declines in loan revenue, operating income of all member banks fell nearly 5 percent, unlike that of District banks which posted a slight gain. Operating expenses in the aggregate dropped more rapidly than income despite a 64 percent increase in loan loss provisions. By contrast, expenses of District member banks showed little change from 1974. The resulting income of all member banks before securities gains and losses increased 1.4 percent, slightly slower than that for District member banks.

\footnotetext{
Incorne and expense items in this article have been adjusted to exclude one bank. Inclusion of this bank, which experienced untusual conditions, would have made the totals for Eighth District member banks unrepresentative and comparisons less meaningful.
}

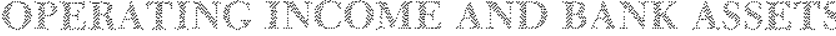

Operating income of Eighth District member banks totalled $\$ 1,581$ million in 1975 , an increase of less than one percent over 1974 (see Table I). By comparison, operating income in 1974 was 29 percent higher than a year earlier. The smaller rise in income in 1975 was the net result of several developments. A restraining force was the 1.3 percent decrease in the volume of loans held by member banks. ${ }^{2}$ The smaller volume, combined with an average rate of return on loans which remained essentially unchanged during the year, resulted in a 2.3 percent decrease in bank earnings on loans. A year earlier, this source of revenue, which is a major portion of total operating income, increased 29 percent.

The volume of total loans outstanding at member banks in the District declined $\$ 149$ million to $\$ 11.6$ billion in 1975. Commercial and industrial loans, the largest single category of loans, registered a 3.4 percent decrease from 1974 - to $\$ 3.6$ billion. Loans to individuals posted a slight decline; outstanding automobile installment loans fell by about 1 percent, while consumer loans remained essentially unchanged. While real estate loans held by Eighth District member banks increased to $\$ 3.4$ billion in 1975 , a rise of 6.8 percent over a year earlier, loan movements were mixed. Loans on one-to-four-family residences showed a 10.3 percent increase, but loans on multi-family property declined by 15 percent.

With the decline in loan volume and an increase in other investments, loans outstanding of District members banks, including Federal funds sold and securities purchased under agreements to resell, accounted for a smaller proportion of total assets in 1975 than in 1974. The share of total assets represented by loans declined about 2 percentage points to 54.6 percent. The proportion of loans to total assets was greater for larger banks than for smaller banks, ranging from an average of 58.3 percent for those banks with $\$ 100$ million or more in deposits to

\footnotetext{
"All comparisons of assets, liabilities, and capital in this article are made as of December 31 of each year.
} 


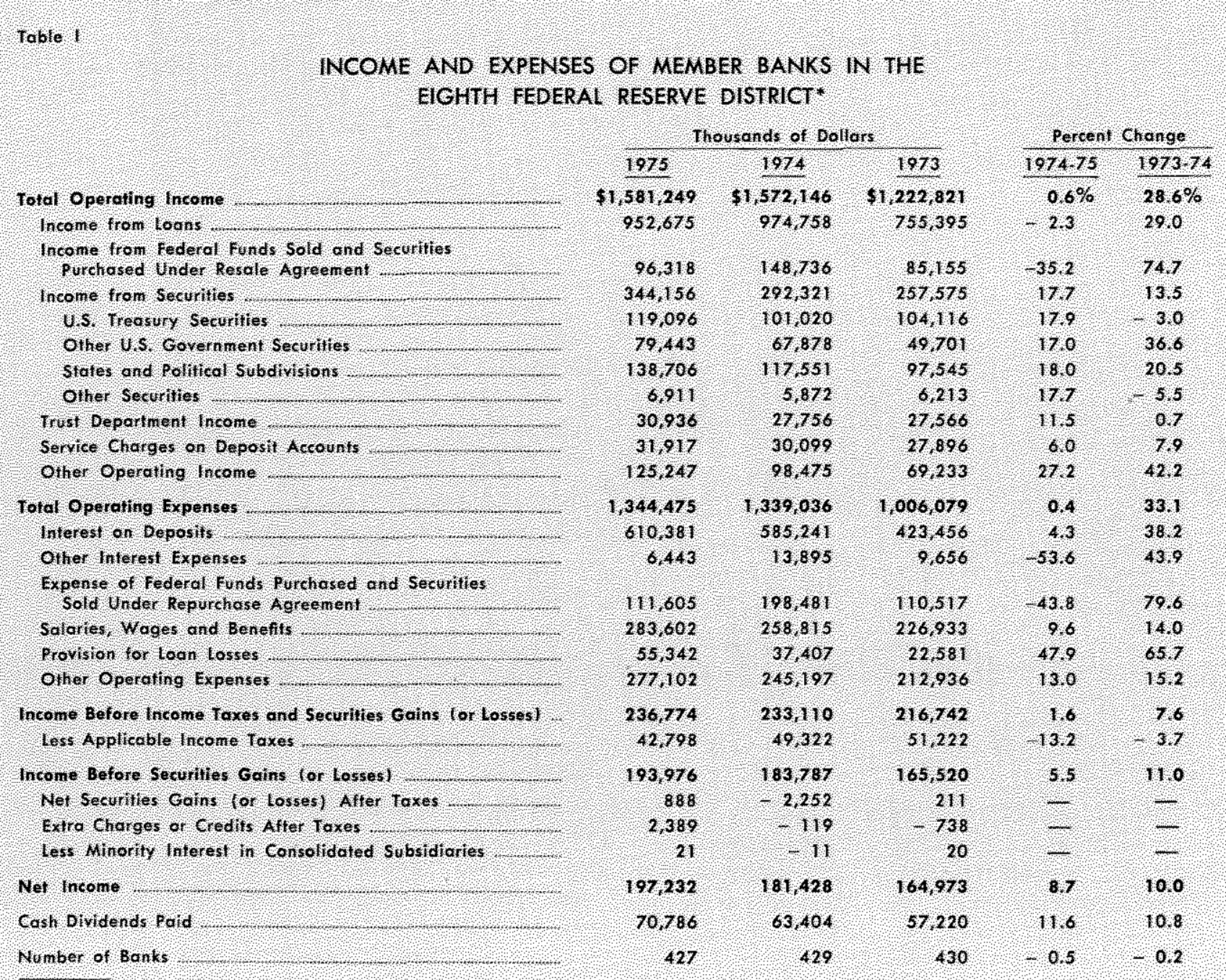

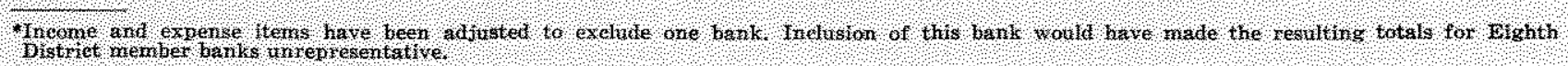

an average of 46.7 percent for those banks with less than $\$ 5$ million in deposits. ${ }^{3}$

The proportion of securities in the asset portfolios of District member banks rose in 1975, emphasizing the increased importance placed on more liquid assets. The proportion of Treasury securities increased 2 percentage points to 8.7 percent of total assets, reversing the downward trend experienced since 1972. Other securities, including obligations of U.S. Government agencies and corporations and those of states and political subdivisions, increased to 17.8 percent from 16.7 percent of total assets.

\footnotetext{
${ }^{3}$ Averages for groups of banks presented in this article are unweighted averages of individual banks' operating ratios. Balance sheet items used in constructing these ratios are averages of the figures from the Reports of Condition of December 1974 and June and December 1975 . Where appropriate, the bank referred to in footnote 1 has beer excluded.
}

Since there was little change in the average realized rates of return on securities, the increased holdings resulted in an 18 percent increase in income from this source. Earnings on all securities totalled $\$ 344$ million in 1975 ; this represented 22 percent of total operating income, up from 19 percent a year earlier. Holdings of U.S. Treasury securities, which accounted for one-third of all investments, rose 35 percent over 1974 . The average rate of return on Treasury securities remained about 6.7 percent in 1975.

Earnings from other securities also rose during the year. Income from U.S. Government corporation and agency securities grew 17 percent, due partly to a 6 percent increase in volume and partly to an increase in the average rate of return-from 6.3 to 6.8 percent. Similarly, earnings from obligations of states and political subdivisions rose 18 percent over 


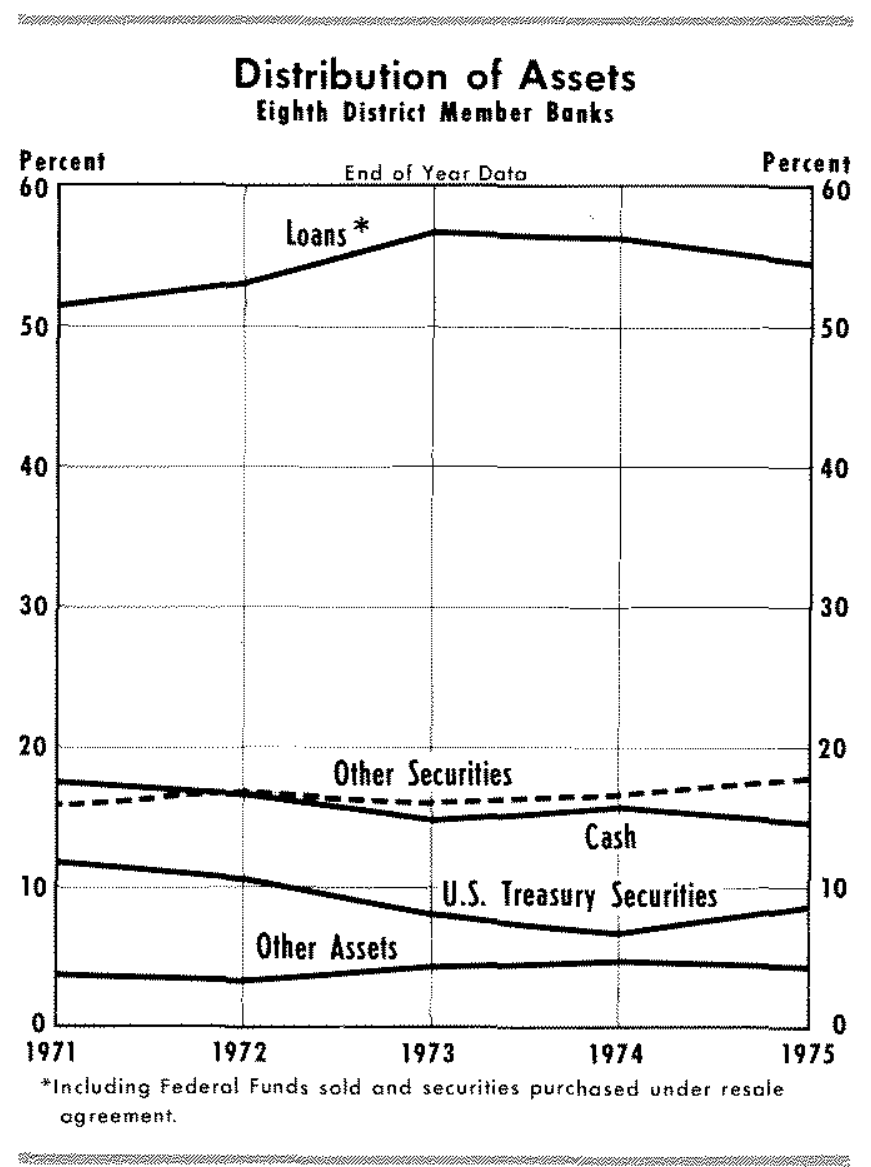

1974, with holdings increasing 6 percent and the average rate of return rising 50 basis points to 4.8 percent. The income provided by these two types of securities rose to 14 percent of total operating income in 1975 , compared to 12 percent a year earlier.

Income from Federal funds sold (overnight advances to other banks) and securities purchased under resale agreements, which accounted for 6 percent of member bank income, fell 35 percent in 1975 . This drop, amounting to $\$ 52$ million, primarily reflected a decline in the Federal funds rate. In 1975 the rate averaged 5.8 percent, compared to 10.5 percent in 1974 .

Operating income of banks also includes income from trust department operations. In 1975, earnings from this source rose 11.5 percent. While it is a relatively minor source of operating income for District member banks in the aggregate, contributing an average of only about 0.6 percent, trust income of banks with $\$ 100$ million or more in deposits accounted for an average of 2.5 percent of their total operating income.

Earnings from service charges on deposit accounts grew 6 percent over 1974, only slightly slower than in the previous year. Income from all other sources, including other fees and service charges and interest on time deposits at other banks, increased 27 percent. These items, however, are relatively minor sources of bank earnings.

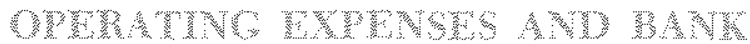

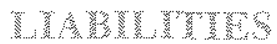

Total operating expenses of Eighth District member banks showed little change in 1975 , rising 0.4 percent to $\$ 1,334$ million. This compares to a 33 percent increase in 1974. Greater outlays for interest on time and savings deposits, wages and salaries, and provisions for loan losses were largely offset by smaller outlays for borrowed funds.

Interest on time and savings deposits, which accounted for 45 percent of member bank expenses, totalled $\$ 610$ million in 1975 . This represents a 4 percent rise over 1974, compared to an increase of 38 percent a year earlier. The slower growth experienced during the year can be attributed to the slower growth of time and savings deposits coupled with the relatively stable average rates paid on these funds. Total time and savings deposits of District member banks rose 11 percent in 1975 to $\$ 11.2$ billion, compared to an increase of 14 percent a year earlier. The average interest rate paid on these deposits remained essentially unchanged, at 5.7 percent. Savings deposits, which account for 31 percent of total time and savings deposits, rose 19 percent over 1974 . Part of this increase may be attributed to a regulatory change introduced in 1975 which allowed corporations to hold up to $\$ 150,000$ in savings deposits.

Despite the slower growth of time and savings deposits in 1975, the ratio of these deposits to total liabilities continued to rise, emphasizing the shifting composition of liabilities. The share of total liabilities accounted for by time and savings deposits increased 3 percentage points in 1975 , to 49 percent. Demand deposits, on the other hand, registered much slower growth. IPC (individuals, partnerships, and corporations) demand deposits rose 4.8 percent in 1975 , while total demand deposits grew by 2.4 percent. The share of total liabilities accounted for by total demand deposits declined slightly to 40 percent of bank liabilities.

Although the amount of interest paid on time and savings deposits increased in 1975, other interest expenses declined. The interest expense from Federal funds purchased (funds borrowed from other banks) and securities sold under repurchase agreements, for 


\section{Distribution of Liabilities, Reserves, and Capital Accounts \\ Eighth Distritł Member Banks}

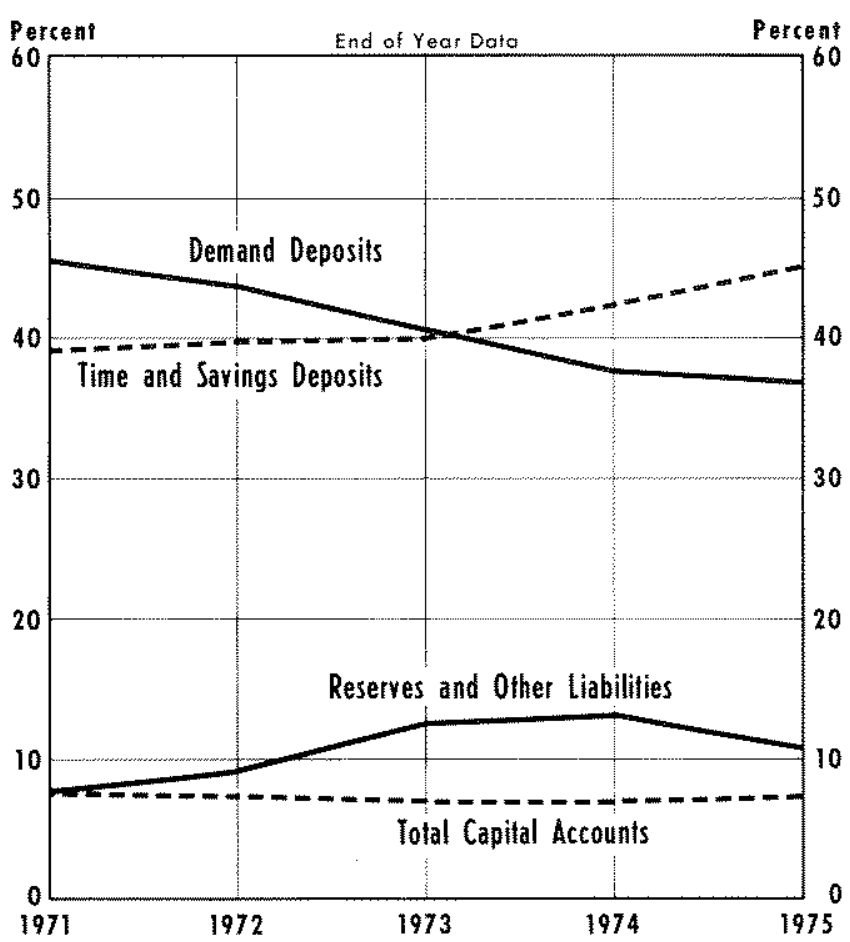

example, dropped 44 percent in 1975. This decline reflects the lower level of interest rates charged for these funds, as noted earlier. Interest expenses on capital notes and debentures and other borrowed money fell 54 percent during 1975. This is due in part to a decrease in the amount of bank borrowing. Liabilities for borrowed money, including Federal funds purchased, fell by 14 percent.

Provision for loan losses is another item classified as an operating expense. Banks maintain a reserve fund for loan losses by charging to current earnings an amount equal to the average of loan losses experienced over the past several years. In years when loan losses are small compared to past experience, provision for loan losses increases the reserve fund available to absorb larger losses when they occur. As losses are written off, they are charged against this reserve instead of directly against current earnings, allowing the loan loss reserve to absorb the shock of unusual losses in a given year.

Reflecting the recession and uncertain financial cli* mate, banks have made substantial increases in the provisions for bad debts in the last two years. In 1975, the provision for loan losses increased 48 percent over 1974 , to $\$ 55$ million. A total of $\$ 12$ million in loans, which had been written off earlier but were recovered in 1975 , and $\$ 7$ million transferred from capital accounts also contributed to increased reserves. Losses charged to these reserves in 1975 amounted to $\$ 61$ million. On balance, reserves on loans and securities increased 2 percent. In 1974, the provision for loan loss reserves increased 66 percent to $\$ 37$ million, while losses charged against reserves totalled $\$ 41$ millilion.

Additional operating expenses registered increases during the year. Salaries, wages, and fringe benefits, a major portion of operating expenses, increased about 10 percent to $\$ 284$ million. The increase in this category, which represents 21 percent of operating expenses, can be broken down into a 9 percent increase in total wages and salaries paid and a 12 percent increase in pensions and other employee benefts. The number of officers and employees rose from 28,804 to 33,442 in 1975 . Other operating expenses, including occupancy, furniture, and equipment costs, totalled $\$ 277$ million, 13 percent higher than in 1974 .

\section{Wh MOMM}

Before income taxes and securities gains or losses, net income of Eighth District member banks totalled $\$ 237$ million in 1975 , an increase of 1.6 percent over 1974. Income taxes of $\$ 43$ million were paid, a 13 percent reduction from 1974. Securities gains and other credits, net of taxes, materially boosted eamings, contributing $\$ 3.3$ million. After adjusting for the net effect of taxes, securities gains, and extraordinary items, net income of member banks increased 9 percent to $\$ 197$ million in 1975 .

Member banks paid cash dividends on common and preferred stock of $\$ 71$ million, a rise of $11.6 \mathrm{per}$ cent over 1974. Cash dividends paid represented 36 percent of net income for all banks, but varied widely by size of banks. Banks with $\$ 5-10$ million in deposits paid cash dividends averaging 18 percent of net income while banks with deposits totalling $\$ 100 \mathrm{mil}$ lion or more paid dividends amounting to 44 percent of net income.

The average rate of return on equity capital, including all reserves, declined in 1975 to 11.2 percent from 12.2 percent a year earlier. By size of bank, this rate varied from an average of 6.7 percent for banks with less than $\$ 5$ million in deposits to 12.3 percent for banks with $\$ 25-50$ million in deposits. Those banks with deposits of $\$ 100$ million or more had an average return of 10.5 percent. 


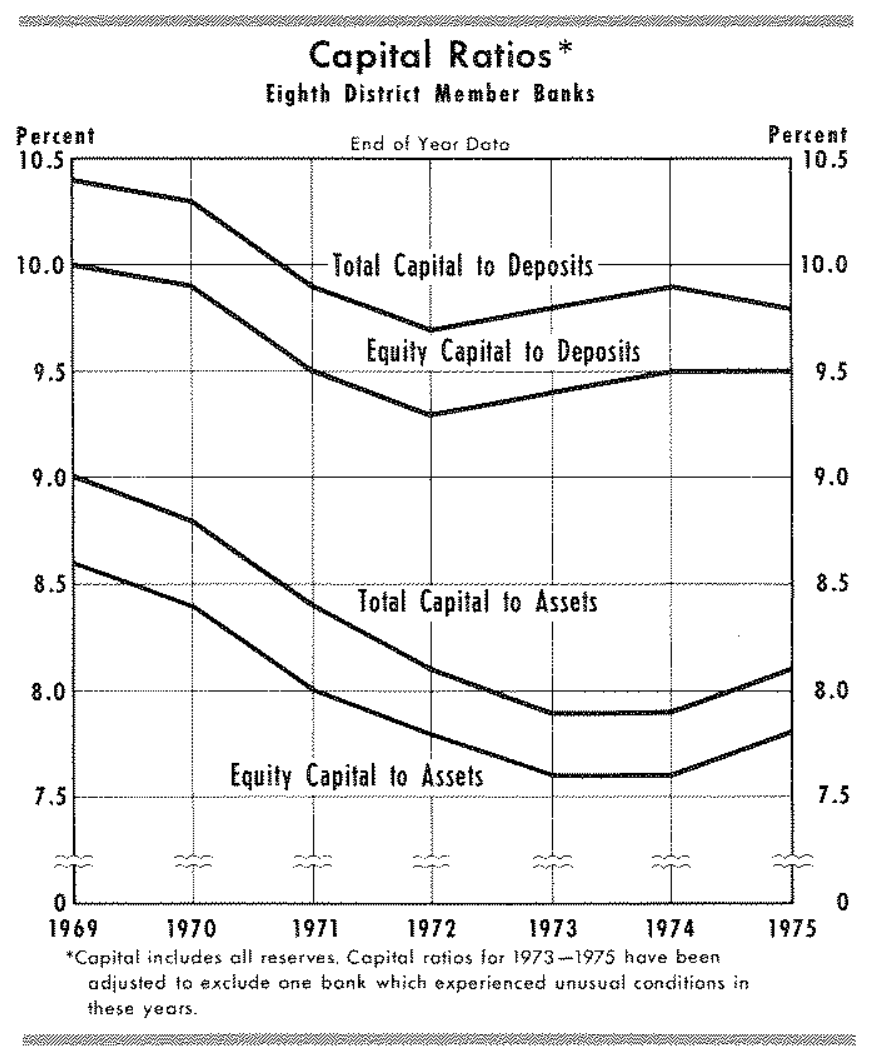

\section{CAPTA. ACOOUNTS AND MANK RATOS}

Total capital of District member banks increased 7.4 percent in 1975 to $\$ 1,777$ million. Equity capital, which accounts for the major portion of total capital, rose 8 percent. After cash dividends of $\$ 71$ million were paid, net retained eamings - the primary source of equity capital - amounted to $\$ 126$ million, 7 percent higher than in 1974 .

Movements of capital ratios were mixed in 1975. While total assets grew 5 percent, total capital rose at a faster 7 percent rate, resulting in an increase in the capital to asset ratio from 7.9 to 8.1 percent. The equity capital to asset ratio also posted an increase, rising 0.2 percentage points to 7.8 percent. These increases represent the first upward movement in these ratios in several years. In 1974 these ratios had leveled off after a period of decline.

Total deposits, on the other hand, grew more rapidly than either of the capital measures. This resulted in a slight decline in the total capital to deposit ratio to 9.8 percent. The ratio of equity capital to deposits remained essentially unchanged at 9.5 percent.

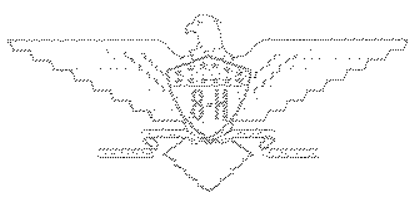

